\title{
Toxicity evaluation of produced formation waters after filtration treatment
}

\author{
Loredana Manfra, Chiara Maggi, Jessica Bianchi, Michela Mannozzi, Olga Faraponova, Livia \\ Mariani, Fulvio Onorati, Andrea Tornambè, Claudia Virno Lamberti, Erika Magaletti
}

ISPRA, Advanced Institute for Environmental Protection and Research, Rome, Italy; loredana.manfra@isprambiente.it

Received 19 June 2009; revised 24 July 2009; accepted 28 July 2009.

\begin{abstract}
During the last years many authors have characterized the produced formation waters $\left(\right.$ PFW $_{\mathrm{s}}$ ) with respect to chemical compounds and toxicity. Most of data are related to $\mathrm{PFW}_{\mathrm{s}}$ collected on offshore platform after treatment process. The available results showed that the particulate phase had an influence on PFW toxicity. Assuming the toxicity of PFW $_{\mathrm{s}}$ treated on platform, the aim of this paper is to study the toxicity of these PFW $_{\mathrm{s}}$ after a further filtration treatment carried out in laboratory. For this purpose PFW $_{\mathrm{s}}$ were sampled from three natural gas platforms located in the Adriatic Sea (Italy) below treatment system. The eco-toxicological bioassays have been conducted on test-organisms belonging to different trophic levels such as bacteria, algae, crustaceans and fishes. The PFW resulted toxic according to an overall assessment obtained through the bioassays. Furthermore, it has been possible to identify the species that were more sensitive to the tested PFW namely Tigriopus fulvus, Dicentrarchus labrax and Vibrio fischeri. Besides, a chemical characterization was reported related to the contaminants present in the PFW $_{s}$ to go with eco-toxicological assessment. Barium, zinc and manganese showed the most concentrations among the metals and the lower molecular weight components were common among the organic compounds. Some differences among PFW $_{\text {s }}$ were observed both for toxicity and chemical composition. The highest toxicity was

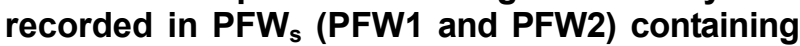
the highest concentrations of some metals (Ba, Mn and $\mathrm{Zn}$ ) and/or BTEX.
\end{abstract}

Keywords: Adriatic Sea (Italy); Offshore Platforms; Natural Gas Production Fields; Produced Formation Waters; Toxicity Assessment; Bacterium (Vibrio
Fischeri); Algae (Dunaliella Tertiolecta and

Phaeodactylum Tricornutum); Crustaceans

(Artemia Franciscana and Tigriopus Fulvus); Fish

(Dicentrarchus Labrax); Chemical Characterization

\section{INTRODUCTION}

Produced formation water (PFW) is water naturally present in sedimentary formations from which oil and gas are mined. It is piped to the surface during the production process and may be discharged into the sea when the rejection is not possible. Before discharge, $\mathrm{PFW}_{\mathrm{s}}$ are treated directly on platform to reduce oil and solid suspended content [1]. In spite of this treatment, $\mathrm{PFW}_{\mathrm{s}}$ still include oil and particles.

In Italy, like in other Countries, the legislation binds to control the oil content in the PFW when they are discharged into the sea [2]; for this reason, the PFW characterization has been limited for several years to measurement of "oil in water", which means analysis of non polar aliphatic hydrocarbons. However, PFW contains a variety of compounds such as metals (i.e. barium, copper, zinc, and iron), volatile aromatic compounds (benzene, toluene, ethylbenzene, xylenes, called BTEX), semivolatile compounds (naphthalene, phenanthrene, dibenzothiophene and their C1-C3 alkyl homologues), phenols alkylated up to $\mathrm{C} 7$, organic acids (C1-C6 compounds) and some additives of possible employment (i.e. diethylene glycol, called DEG) [3].

For this reason, during the last years many authors have characterized $\mathrm{PFW}_{\mathrm{s}}$ with respect to these compounds (metals, aromatic and aliphatic hydrocarbons, phenols and additives) and to the toxicity of $\mathrm{PFW}_{\mathrm{s}}$.

The most data-gathering is related to $\mathrm{PFW}_{\mathrm{s}}$ collected on platform after treatment process and untreated in laboratory later on [4-8]. Few data are referred to $\mathrm{PFW}_{\mathrm{s}}$ collected on oil platforms below treatment system and filtered in laboratory subsequently [3,9].

There are scattered data about $\mathrm{PFW}_{\mathrm{s}}$ originated from Italian offshore gas installations (Adriatic Sea): some 
chemical analyses were made on seawaters and mussels near Adriatic platforms [10]; a methodological approach was proposed to study the environmental impact of oil and gas offshore platforms [11]; preliminary results were published on metal content and toxicity of $\mathrm{PFW}_{\mathrm{s}}$ coming from gas Adriatic platforms [12-15].

In these studies, the $\mathrm{PFW}_{\mathrm{s}}$ generally showed to be toxic and their toxicity was higher for samples unfiltered in laboratory. This effect was observed probably because of particulate phase influence. The effects of particulate could be to mechanic level (oral ingestion and digestion) and/or a chemical process (adsorption) [7,12].

The aim of this paper was to investigate the toxicity of $\mathrm{PFW}_{\mathrm{s}}$ originated from three natural gas platforms in the Adriatic Sea (Italy). These $\mathrm{PFW}_{\mathrm{s}}$ were collected below treatment system occurred on platforms and then filtered in laboratory. Their toxicity was evaluated using the integrated response of many species. The eco-toxicological battery included six species belonging to different trophic levels: a bacterium (Vibrio fischeri) representative of the debris chain, two algae species (Dunaliella tertiolecta and Phaeodactylum tricornutum) as primary producers, two crustaceans (Artemia franciscana and Tigriopus fulvus) as primary consumers and a fish (Dicentrarchus labrax) as representative of the highest trophic level (secondary consumer).

Besides, a chemical characterization of $\mathrm{PFW}_{\mathrm{s}}$ was reported to go with eco-toxicological assessment. We investigated the metals, BTEX, PAHs and DEG. Metals and PAHs were analyzed both in filtered and particulate $\mathrm{PFW}_{\mathrm{s}}$, because these compounds are present above all as particles $[7,16]$. BTEX and DEG were recorded directly in the whole sample of PFW $_{\mathrm{s}}$. This choice was necessary because BTEX are partitioned between gas and liquid phases, therefore the particulate matter does not influence their concentration; moreover they are volatile compounds and the filtration procedure causes loss of analytes. DEG was also analyzed in unfiltered sample because it is highly soluble in water, not much volatile and it does not tend toward absorption on particles [17].

Analytical methods by themselves were not able to give information on what happens when organisms are exposed to $\mathrm{PFW}_{\mathrm{s}}$, which concentrations are toxic and which is ecological impact of a PFW discharge. The use of bioassays, together with the classic chemical analyses, can contribute to the understanding of these aspects.

\section{MATERIALS AND METHODS}

\subsection{Sampling and Sample Treatment of Produced Formation Water (PFW)}

PFW samples were collected from three different gas platforms situated at about $20 \mathrm{~km}$ off the Adriatic coast (Pescara and Rimini, Italy): one of these (PFW1) was collected in October 2005 and the other two (PFW3 and PFW2) in June 2006.

On offshore platforms PFW is stored in a tank which empties when it is full load. All $\mathrm{PFW}_{\mathrm{s}}$ were sampled from a tap located on the platform, which receives the PFW after this has had a physical-chemical treatment (depressurization, gravity separation techniques, activated carbon filtration). The physical-chemical parameters of $\mathrm{PFW}_{\mathrm{s}}$ (salinity, $\mathrm{pH}$, conductibility, ORP and oxygen dissolved) were measured in laboratory by multi-parameter probe (YSI, mod. 556MPS) (Table 1).

For the bioassays, about ten litres of PFW were immediately filtered (Millipore ${ }^{\circledR}, 0.45 \mu \mathrm{m}$ ) and refrigerated in polystyrene vessels at $4^{\circ} \mathrm{C}$ until their execution. The bioassays were carried out in 72 hours.

The $\mathrm{PFW}_{\mathrm{s}}$ were stored in different containers according to type of chemical analyses. For the metals two litres were filtered (Millipore $\AA$, $0.45 \mu \mathrm{m}$ ), acidified with high purity nitric acid and refrigerated at $4^{\circ} \mathrm{C}$ until analysis; the filters were stored at $-20^{\circ} \mathrm{C}$. For BTEX 10 $\mathrm{mL}$ of PFW were stored in SPME dark vials (Varian S. p. A); a magnetic stirrer bar was inserted in each vial prior to sealing the vial by magnetic steel closures equipped with Teflon septa. The vials were refrigerated at $4^{\circ} \mathrm{C}$ and the samples were acidified at $\mathrm{pH}=2$ with $\mathrm{HCl}$ and saturated with $\mathrm{NaCl}$. For the PAHs analysis, one litre of PFW was immediately filtered (Millipore ${ }^{\circ}, 0.45 \mu \mathrm{m}$ ) and, together with the filters, stored at $4^{\circ} \mathrm{C}$. For the DEG analysis one litre of sample was collected in dark glass bottles, saturated with mercury chloride and refrigerated at $4^{\circ} \mathrm{C}$ to avoid photochemical and bacterial activity.

\subsection{Bioassays}

The bioassays were carried out on filtered samples, according to the methods reported in Table 2 and summarized for each taxon as follows:

Bacteria: Controls and different concentrations for each PFW sampled (dilution ratio 1:2) were tested according to the Basic Protocol [18] and the method ISO [19] with

Table 1. Physical-chemical parameters of production formation water and information on platforms.

\begin{tabular}{cccccccccc}
\hline PFW & $\begin{array}{c}\text { Salinity } \\
\text { (PSU) }\end{array}$ & pH & $\begin{array}{c}\text { Conductibility } \\
\left(\mathrm{mS} / \mathrm{cm}^{2}\right)\end{array}$ & ORP & $\begin{array}{c}\text { Oxygen } \\
\text { dissolved } \\
(\%)\end{array}$ & $\begin{array}{c}\text { Volume flux of } \\
\text { PFW (mc/year) }\end{array}$ & $\begin{array}{c}\text { Platform } \\
\text { Installation } \\
\text { (year) }\end{array}$ & $\begin{array}{c}\text { Platform distance } \\
\text { from coast (Km) }\end{array}$ & $\begin{array}{c}\text { Water } \\
\text { depth } \\
(\mathrm{m})\end{array}$ \\
\hline PFW1 & 34 & 7 & 51 & -100 & 93 & 6000 & 1991 & 36 & 116 \\
PFW2 & 37 & 7 & 56 & -105 & 96 & 3000 & 1972 & 15 & 18 \\
PFW3 & 37 & 8 & 55 & -70 & 86 & 3000 & 1991 & 21 & 23 \\
\hline
\end{tabular}


bacteria coming from freeze-dried SDI. PFW salinity was not adjusted prior to testing. The Software Microtox Om$\mathrm{ni}^{\mathrm{TM}}$ v. 1.16 was utilized to calculate the $\mathrm{EC}_{50}$ and $\mathrm{EC}_{20}$ values (effect concentration of $50 \%$ and $20 \%$ respectively) and the Dunnett test was used to calculate the NOEC value (no observed effect concentration).

Algae: One control and some concentrations for each PFW sampled were tested according to the ISO method [20] with Phaeodactylum tricornutum strain $1090-1^{\circ}$ and Dunaliella tertiolecta strain 13.86, obtained from the Plant Physiology Institute of Gottingen University (Germany). Algal growth medium was prepared with artificial seawater [20]; for D. tertiolecta nutrients, according to the IRSA-CNR method [21] and vitamins according to the ISO method [20] were added. The algal inoculum had an initial density of 10000 cells $\mathrm{mL}^{-1} \pm 10 \%$ for $P$. tricornutum and 2000 cells $\mathrm{mL}^{-1} \pm 10 \%$ for $D$. tertiolecta. Regression analysis technique was performed for the determination of $\mathrm{EC}_{50}$ and $\mathrm{EC}_{20}$; the Dunnett test was used to calculate the NOEC value.

Crustaceans: A control and some concentrations for each PFW sampled were tested with nauplii of Artemia franciscana, according to the APAT IRSA-CNR method [22], and with nauplii of Tigriopus fulvus, according to the ISO/FDIS method [23] as modified by Faraponova et al. [24,25]. Reference cysts of A. franciscana were obtained from the Quality Assurance Research Division U. S. Environmental Protection Agency (Cincinnati $\mathrm{OH} 45268$, USA) or from the Laboratory for Biological Research in Aquatic Pollution, University of Ghent (Belgium). The eggs of $A$. franciscana were hatched in synthetic seawater and the nauplii were used within 48 hours of hatching [22]. Synchronized nauplii (24-48h) of $T$. fulvus were collected from a culture of two hundred females taken from a mass laboratory culture originated from the Italian coast (Calafuria, Livorno) and supplied with an algal mixture (Tetroselmis suecica and Isochrysis galbana, ratio $1: 2)$. Probit analysis was performed for the determination of $\mathrm{EC}_{50}$ and $\mathrm{EC}_{15}$, the Dunnett test was used to calculate the NOEC value.

Fish: One control and some concentrations for each PFW sampled were tested with juveniles of Dicentrarchus labrax (80 days old, length of $3.74 \pm 0.28 \mathrm{~cm}$ and weight of $0.48 \pm 0.08 \mathrm{~g}$ ), according to the EPA [26] and OECD [27] methods. Organisms were supplied by the hatchery production plant ASA (Rome), stabled in synthetic seawater with salinity of $20 \pm 1$ PSU for 15 days and fed with granulated food until 24 hours before the test. Probit analysis was performed for the determination of $\mathrm{EC}_{50}$ and $\mathrm{EC}_{15}$, the Dunnett test was used to calculate the NOEC value.

The results were compared to a toxicity scale reported in Table 3. On the basis of this toxicity scale, the samples were classified as follows: 1) toxic $10 \leq \mathrm{EC}_{50}<100,20 \leq$ $\mathrm{EC}_{20}<50$, effect percentage $\geq 50 ; 2$ ) weakly toxic $\mathrm{EC}_{50}>100$, $\mathrm{EC}_{20}>50,20 \leq$ effect percentage $\left.<50 ; 3\right)$ no toxic $\mathrm{EC}_{50}$ no calculable, $\mathrm{EC}_{20}>100$, effect percentage 20 .

\subsection{Analysis of Metals}

Determination of iron $(\mathrm{Fe})$, copper $(\mathrm{Cu})$, zinc $(\mathrm{Zn})$, lead $(\mathrm{Pb})$, chromium $(\mathrm{Cr})$, manganese $(\mathrm{Mn})$, nickel $(\mathrm{Ni})$, barium $(\mathrm{Ba})$, arsenic (As), cadmium (Cd) and mercury (Hg) was carried on both filtered and particulate samples. The filtered sample was directly analyzed. The metal dissolution of particulate fraction collected on the filters was conducted using microwave-assisted digestion (Milestone MLS Ethos TC) with $3 \mathrm{~mL}$ of $\mathrm{HNO}_{3}$ and $9 \mathrm{~mL}$ of $\mathrm{HCl}$. The metal concentrations were determined by a graphite furnace atomic absorption with Zeeman background correction technique (SpectrAA-220Z, Varian) and by coupled emission plasma ICP-OES (Liberty AX, Varian). For $\mathrm{Hg}$ analysis a Direct Mercury Analyzer (DMA-80, FKV) instrument was used (EPA Method [28]). All samples were run in triplicate. The quantification limits (LOQ) were: $0.0005 \mathrm{mg} / \mathrm{l}$ for $\mathrm{Hg}$ and $\mathrm{Cd}, 0.01$ $\mathrm{mg} / \mathrm{L}$ for the other metals.

\subsection{Analysis of Organic Compounds}

BTEX: The analyses were extracted and pre-concentrated by means Solid Phase Micro Extraction (SPME) using a stable flex fiber of divinilbenzene-carboxenpoly-dimethylsiloxane (film thickness: 55/30 $\mu \mathrm{m}$ ) (Supelco $^{\circledR}$ ) by head space sampling. The analytical determinations of BTEX were carried out in unfiltered samples using a modified EPA method [29]. A gas chromatography coupled with mass spectrometry (GC HP 5790 Agilent Technologies ${ }^{\circledR}$ and MS 5973 Network Agilent Technologies ${ }^{\mathbb{B}}$ ) were used. The method detection limits were $1 \mu \mathrm{g} / \mathrm{L}$ for benzene and $0.1 \mu \mathrm{g} / \mathrm{L}$ for toluene, ethyl benzene and xylenes.

PAHs: The analyses were investigated in filtered samples and on the particulate matter retained by the filter (Millipore $\left.^{\circledR}, 0.45 \mu \mathrm{m}\right)$. The analyses were extracted by the filtered samples by means Solid Phase Extraction technique. The treatment of filters was carried out by ultrasonic extraction for 20 minutes with $10 \mathrm{~mL}$ of dichloromethane. Then, both the extraction phases were evaporated at 1-2 $\mathrm{mL}$ with a gentle nitrogen flow. Afterward, $1 \mathrm{~mL}$ of toluene was added and the residual dichloromethane was completely removed. All solvents were capillary GC grade supplied by Sigma-Aldrich. The analyses of PAHs were carried out in gas chromatography coupled with mass spectrometry (GC HP $5790^{\circledR}$ and MS 5973 Network Agilent Technologies). The LOQ was $1 \mu \mathrm{g} / \mathrm{L}$ for each analysis.

DEG: An extraction procedure of DEG was carried out with $2 \mathrm{~mL} \mathrm{SPE}$ cartridges packed with $200 \mathrm{mg}$ of EN $\mathrm{V}+$ stationary phase (International Sorbent Technology, 
Table 2. Experimental conditions of bioassays ( ${ }^{*}$ for PFW1 were tested the concentrations: $10-20-40-80 \%$ ).

\begin{tabular}{|c|c|c|c|c|c|c|}
\hline & $\begin{array}{l}\text { Vibrio } \\
\text { fischeri }\end{array}$ & $\begin{array}{l}\text { Phaeodactylum } \\
\text { tricornutum }\end{array}$ & $\begin{array}{l}\text { Dunaliella } \\
\text { tertiolecta }\end{array}$ & $\begin{array}{c}\text { Artemia } \\
\text { franciscana }\end{array}$ & Tigriopus fulvus & $\begin{array}{c}\text { Dicentrarchus } \\
\text { labrax }\end{array}$ \\
\hline $\begin{array}{l}\text { Organisms/ } \\
\text { Life stage }\end{array}$ & cells & $\begin{array}{l}\text { unialgal } \\
\text { culture }\end{array}$ & $\begin{array}{l}\text { unialgal } \\
\text { culture }\end{array}$ & nauplii $48 \mathrm{~h}$ & nauplii $48 \mathrm{~h}$ & juveniles \\
\hline Strain/origin & $\begin{array}{l}\text { commercially } \\
\text { available }\end{array}$ & culture & culture & $\begin{array}{l}\text { commercially } \\
\text { available }\end{array}$ & culture & hatchery \\
\hline Type of test & static & static & static & static & static & static \\
\hline Time exposure & $5-10-15 \mathrm{~min}$ & $72 \mathrm{~h}$ & $72 \mathrm{~h}$ & $96 \mathrm{~h}$ & $96 \mathrm{~h}$ & $96 \mathrm{~h}$ \\
\hline Intensity of lux & Not required & 7000 & 7000 & $3000-4000$ & $500-1200$ & $500-800$ \\
\hline $\begin{array}{l}\text { Photoperiod } \\
\text { (L:D) }\end{array}$ & Not required & $24: 0$ & $24: 0$ & $14: 10$ & $16: 8$ & $16: 8$ \\
\hline $\begin{array}{l}\text { Dilution water/ } \\
\text { control }\end{array}$ & $\begin{array}{l}\text { synthetic } \\
\text { seawater }\end{array}$ & synthetic seawater & synthetic seawater & synthetic seawater & $\begin{array}{l}\text { synthetic sea- } \\
\text { water }\end{array}$ & synthetic seawater \\
\hline Salinity (PSU) & 35 & 32 & 32 & 35 & 38 & 20 \\
\hline $\begin{array}{l}\text { Temperature } \\
\left({ }^{\circ} \mathrm{C}\right)\end{array}$ & $15 \pm 1$ & $20 \pm 2$ & $20 \pm 2$ & $25 \pm 2$ & $18 \pm 2$ & $20 \pm 1$ \\
\hline pH & $8.0-8.2$ & $8 \pm 0.5$ & $8 \pm 0.5$ & $6.5-8.5$ & $8.0 \pm 0.3$ & $7.5 \pm 0.5$ \\
\hline Vessel & $5 \mathrm{~mL}$ & $100 \mathrm{~mL}$ & $100 \mathrm{~mL}$ & $50 \mathrm{~mL}$ & $\begin{array}{l}\text { culture plates } 12 \\
\text { wells }\end{array}$ & $2000 \mathrm{~mL}$ \\
\hline Volume/well & $1 \mathrm{~mL}$ & $25 \mathrm{~mL}$ & $25 \mathrm{~mL}$ & $40 \mathrm{~mL}$ & $3 \mathrm{~mL}$ & $1800 \mathrm{~mL}$ \\
\hline $\mathbf{N}^{\circ}$ organisms/well & - & $10000 / \mathrm{mL}$ & $2000 / \mathrm{mL}$ & 10 & 10 & 5 \\
\hline $\begin{array}{l}\mathrm{N}^{\circ} \text { of concentra- } \\
\text { tions (Range) }\end{array}$ & $\begin{array}{c}5 \\
-(6-11-22-45-90 \%)\end{array}$ & $\frac{5}{(6-12-25-50-100 \%)^{*}}$ & *(6-12-25-50-100\%) & $\begin{array}{c}5 \\
(6-12-25-50-100 \%)\end{array}$ & $\begin{array}{c}5 \\
(5-10-20-40-80 \%)\end{array}$ & $\begin{array}{c}5 \\
(6-12-25-50-100 \%)\end{array}$ \\
\hline $\mathrm{N}^{\circ}$ of replicates & 3 & 3 & 3 & 3 & $3-4$ & 3 \\
\hline $\begin{array}{l}\text { Feeding during } \\
\text { the test }\end{array}$ & absent & absent & absent & D. tertiolecta & absent & absent \\
\hline Endpoint/Effect & $\begin{array}{l}\text { bioluminescence } \\
\text { inhibition rate }\end{array}$ & $\begin{array}{c}\text { growth inhibition } \\
\text { rate }\end{array}$ & $\begin{array}{c}\text { growth inhibition } \\
\text { rate }\end{array}$ & $\begin{array}{l}\text { immobilization } \\
\text { rate }\end{array}$ & $\begin{array}{c}\text { mortality rate; } \\
\text { moult release rate }\end{array}$ & mortality rate \\
\hline $\begin{array}{l}\text { Expression of } \\
\text { endpoint }\end{array}$ & $\begin{array}{c}\mathrm{EC}_{50} ; \mathrm{EC}_{20} \\
\mathrm{NOEC}\end{array}$ & $\begin{array}{c}\mathrm{EC}_{50} ; \mathrm{EC}_{20} \\
\mathrm{NOEC}\end{array}$ & $\begin{array}{c}\mathrm{EC}_{50} ; \mathrm{EC}_{20} \\
\mathrm{NOEC}\end{array}$ & $\begin{array}{c}\mathrm{EC}_{50} ; \mathrm{EC}_{15} \\
\mathrm{NOEC}\end{array}$ & $\begin{array}{c}\mathrm{EC}_{50} ; \mathrm{EC}_{15} \\
\mathrm{NOEC}\end{array}$ & $\begin{array}{c}\mathrm{EC}_{50} ; \mathrm{EC}_{15} \\
\mathrm{NOEC}\end{array}$ \\
\hline $\begin{array}{l}\text { Acceptability } \\
\text { (effect control) }\end{array}$ & $\leq 10 \%$ & $>0.04 / \mathrm{h}$ & $>0.04 / \mathrm{h}$ & $\leq 10 \%$ & $\begin{array}{c}\leq 10 \% \text { (mortality) } \\
\leq 20 \% \text { (moult } \\
\text { release) }\end{array}$ & $\leq 10 \%$ \\
\hline
\end{tabular}

Glamorgan, UK). The off-line solid-phase extraction/ pre-concentration technique was followed by a nanoscale flow injection/direct-electron ionization (EI) mass spectrometric analysis. A quadrupole mass spectrometer (Palo Alto, CA) was coupled with a Direct-Electron Ionization (EI) [30-32]. Using this approach, DEG was detected within a concentration of $31 \mu \mathrm{g} / \mathrm{L}$ [33].

Table 3. Toxicity scale used in this paper to classify the toxicity of Production Formation Water (PFW).

\begin{tabular}{cccc}
\hline $\begin{array}{c}\text { Effect } \\
(\%)\end{array}$ & $\begin{array}{c}\text { EC50 } \\
(\%)\end{array}$ & $\begin{array}{c}\text { EC20 or } \\
\text { EC15 }(\%)\end{array}$ & $\begin{array}{c}\text { TOXICITY } \\
\text { ASSESSMENT }\end{array}$ \\
\hline$\%<20$ & n.c. & $>100$ & no toxic \\
$20 \leq \%<50$ & $>100$ & $>50$ & weakly toxic \\
$\geq 50$ & $10 \leq \%<100$ & $20<\%<50$ & toxic \\
\hline
\end{tabular}

\section{RESULTS}

\subsection{Bioassays}

The results of the eco-toxicological battery are reported in Table 4. The three filtered $\mathrm{PFW}_{\mathrm{s}}$ resulted toxic according to the overall assessment related to bioassays. The species showed different sensitivity to PFW: the two microalgae and Artemia franciscana showed higher values of $\mathrm{EC}_{50}$ and $\mathrm{EC}_{20}\left(\mathrm{EC}_{15}\right)$ than the other organisms, indicating weak toxicity. In particular, Artemia did not record toxicity for PFW1 (no efficient concentration was calculable). The other crustacean $T$. fulvus showed toxic effects for all $\mathrm{PFW}_{\mathrm{s}}(\mathrm{PFW} 2>\mathrm{PFW} 1 \geq \mathrm{PFW} 3)$ related to both mortality and moult release. The sub-lethal effect was already observed at PFW concentrations that were not causing mortality of nauplii $(20-80) \%$. The fish species $D$. labrax showed a toxic response similar to the one of T. fulvus, with a minimum value of $\mathrm{EC}_{50}$ equal to $15 \%$ and maximum value of $47 \%$ as follows: PFW2 $>$ PFW1 $\geq$ 
PFW3. The bacterium $V$. fischeri recorded lower toxicity than T. fulvus and D. labrax but yet a toxic effect was observed for all $\mathrm{PFW}_{\mathrm{S}}(\mathrm{PFW} 1>\mathrm{PFW} 3 \geq \mathrm{PFW} 2)$.

\subsection{Analysis of Metals}

In filtered sample, $\mathrm{Ba}, \mathrm{Mn}$ and $\mathrm{Zn}$ showed detectable concentrations. There were not significant differences between PFW2 and PFW3 exclusive of $\mathrm{Ba}$ and $\mathrm{Mn}$. These two metals showed higher concentrations of one order in PFW2 than PFW3. In particulate sample, all metals were detectable except $\mathrm{Pb}$ and $\mathrm{Hg}$. $\mathrm{Ni}, \mathrm{Cd}$ and $\mathrm{As}$ registered detectable concentrations only in PFW3. Ba, $\mathrm{Zn}$ and $\mathrm{Fe}$ showed highest concentrations and some significant differences among the $\mathrm{PFW}_{\mathrm{s}}$ analyzed. Ba concentration was higher of one order in PFW1 and PFW2 than PFW3; Zn was higher of two orders in PFW2 and PFW3 than PFW1; Fe was higher of one order in PFW3 than PFW1 and PFW2.

\subsection{Analysis of Organic Compounds}

As reported in introduction section, BTEX and DEG were analysed on unfiltered $\mathrm{PFW}_{\mathrm{s}}$. The analyses of the three platforms pointed out that the volatile organic compounds (BTEX) were detected at very high concentrations by the following ranking: PFW1 $(1281.8 \mu \mathrm{g} / \mathrm{L})$
>PFW3 (66.5 $\mu \mathrm{g} / \mathrm{L})>$ PFW2 (48.0 $\mu \mathrm{g} / \mathrm{L})$ (Table 6), showing for PFW1 values almost twenty times higher than ones of PFW2 and PFW3. The DEG showed concentrations ranging from 2400 to $13000 \mu \mathrm{g} / \mathrm{L}$ by the following ranking of the fields: PFW3 $>$ PFW2 $>$ PFW1 (Table 6). PAHs were investigated both in filtered and particulate sample but they were lower than LOQ $(1 \mu \mathrm{g} / \mathrm{L})$ in filtered $\mathrm{PFW}_{\mathrm{s}}$. In particulate sample PAHs showed the trend as follows: PFW1 (150.0 $\mu \mathrm{g} / \mathrm{L})>$ PFW3 (126.0 $\mu \mathrm{g} / \mathrm{L})>$ PFW2 $(100.0 \mu \mathrm{g} / \mathrm{L})$, with values about of the same magnitude order. The congeners with two and three rings recorded the following concentrations: 87 $\mu \mathrm{g} / \mathrm{L}$ in PFW1 compared to $150 \mu \mathrm{g} / \mathrm{L}$ of the total PAHs content; $54 \mu \mathrm{g} / \mathrm{L}$ in PFW2 compared to $100 \mu \mathrm{g} / \mathrm{L}$ of total PAHs concentration, and $66 \mu \mathrm{g} / \mathrm{L}$ in PFW3 compared to $126 \mu \mathrm{g} / \mathrm{L}$ of total PAHs. The detected concentrations were of the same order of magnitude for all three PFW investigated.

\section{DISCUSSIONS}

The bioassays showed that the $\mathrm{PFW}_{\mathrm{s}}$ were toxic even if filtered. $\mathrm{EC}_{50}$ values ranged between the minimum of $14.8 \%$ and values higher than $100 \%$. Some of the samples did record no toxicity at the $\mathrm{EC}_{50}$ level observed

Table 4. Bioassay results related to three Italian Production Formation Waters and toxicity evaluation according to toxicity scale (n.c. not calculable; n.d. not determined).

\begin{tabular}{|c|c|c|c|c|c|c|c|}
\hline $\begin{array}{c}\text { Species } \\
\text { (time of exposure, end point) }\end{array}$ & $\%$ & PFW1 & PFW2 & PFW3 & PFW1 & PFW2 & PFW3 \\
\hline $\begin{array}{c}\text { Vibrio fischeri } \\
\text { (15 min. bioluminescence) }\end{array}$ & $\begin{array}{c}\mathrm{EC}_{50} \\
\mathrm{EC}_{20} \\
\mathrm{NOEC} \\
\mathrm{EC}_{50}\end{array}$ & $\begin{array}{c}67(59-75) \\
20(18-23) \\
- \\
>80\end{array}$ & $\begin{array}{c}>90 \\
29(27-31) \\
- \\
>100\end{array}$ & $\begin{array}{c}>90 \\
28(25-31) \\
- \\
>100\end{array}$ & toxic & toxic & toxic \\
\hline $\begin{array}{c}\text { Phaeodactylum tricornutum } \\
\text { (72h growth) }\end{array}$ & $\mathrm{EC}_{20}$ & $>80$ & $\begin{array}{c}52 \\
(46-58)\end{array}$ & $\begin{array}{c}68 \\
(24-111)\end{array}$ & $\begin{array}{l}\text { weakly } \\
\text { toxic }\end{array}$ & $\begin{array}{l}\text { weakly } \\
\text { toxic }\end{array}$ & $\begin{array}{l}\text { weakly } \\
\text { toxic }\end{array}$ \\
\hline $\begin{array}{l}\text { Dunaliella tertiolecta } \\
\text { (72h growth) }\end{array}$ & $\begin{array}{c}\text { NOEC } \\
\mathrm{EC}_{50} \\
\mathrm{EC}_{20} \\
\mathrm{NOEC} \\
\mathrm{EC}_{50}\end{array}$ & $\begin{array}{c}40 \\
>80 \\
>80 \\
40 \\
>100\end{array}$ & $\begin{array}{c}25 \\
\text { n.d. } \\
\text { n.d } \\
\text { n.d } \\
>100\end{array}$ & $\begin{array}{c}25 \\
\text { n.d } \\
\text { n.d } \\
\text { n.d } \\
>100\end{array}$ & $\begin{array}{l}\text { weakly } \\
\text { toxic }\end{array}$ & n. $\mathrm{d}$ & n. d. \\
\hline $\begin{array}{l}\text { Artemia franciscana } \\
\text { (96h immobilization) }\end{array}$ & $\mathrm{EC}_{15}$ & $>100$ & $\begin{array}{c}86 \\
(55-259)\end{array}$ & $\begin{array}{c}77 \\
(42-462)\end{array}$ & no toxic & $\begin{array}{l}\text { weakly } \\
\text { toxic }\end{array}$ & $\begin{array}{l}\text { weakly } \\
\text { toxic }\end{array}$ \\
\hline $\begin{array}{l}\text { Tigriopus fulvus } \\
\text { (96h mortality) }\end{array}$ & $\begin{array}{c}\mathrm{NOEC} \\
\mathrm{EC}_{50} \\
\mathrm{EC}_{15} \\
\mathrm{NOEC}\end{array}$ & $\begin{array}{l}\text { n.c. } \\
29 \\
19 \\
10\end{array}$ & $\begin{array}{c}50 \\
15 \\
8 \\
5\end{array}$ & $\begin{array}{l}25 \\
44 \\
29 \\
20\end{array}$ & toxic & toxic & toxic \\
\hline $\begin{array}{l}\text { Tigriopus fulvus } \\
\text { (96h moult release) }\end{array}$ & $\begin{array}{c}\mathrm{EC}_{50} \\
\mathrm{EC}_{15} \\
\mathrm{NOEC}\end{array}$ & $\begin{array}{c}23 \\
\text { n.c. } \\
10\end{array}$ & $\begin{array}{c}25 \\
\text { n.c. } \\
5\end{array}$ & $\begin{array}{c}77 \\
\text { n.c. } \\
10\end{array}$ & toxic & toxic & toxic \\
\hline $\begin{array}{l}\text { Dicentrarchus labrax } \\
\text { (96h mortality) }\end{array}$ & $\begin{array}{c}\mathrm{EC}_{50} \\
\mathrm{EC}_{15} \\
\mathrm{NOEC}\end{array}$ & $\begin{array}{c}32 \\
(27-39) \\
23 \\
(15-28) \\
13\end{array}$ & $\begin{array}{c}15 \\
\text { (n.c) } \\
11 \\
\text { (n.c) } \\
6\end{array}$ & $\begin{array}{c}47 \\
\text { (n.c) } \\
15 \\
\text { (n.c) } \\
6\end{array}$ & toxic & toxic & toxic \\
\hline
\end{tabular}


Table 5. Metal concentrations in filtered samples of two Produced Formation Waters, total suspended solids and metal concentrations in particulate samples of Produced Formation Water from three offshore gas platforms in the Adriatic Sea (Italy).

\begin{tabular}{ccccccc}
\hline Parameters & Unit & PFW2 & PFW3 & PFW1 & PFW2 & PFW3 \\
\hline \multicolumn{7}{c}{ FILTERED } \\
Total suspended solid & $\mathrm{mg}$ & \multicolumn{4}{c}{ PARTICULATE } \\
$\mathrm{Ba}$ & $\mathrm{mg} / \mathrm{L}$ & 1.63 & 0.13 & 177.42 & 367.05 & 398.10 \\
$\mathrm{Cr}$ & $\mathrm{mg} / \mathrm{L}$ & $<0.01$ & $<0.01$ & 0.12 & 1.34 & 13.50 \\
$\mathrm{Cu}$ & $\mathrm{mg} / \mathrm{L}$ & $<0.01$ & $<0.01$ & 0.05 & 0.55 & 0.45 \\
$\mathrm{Mn}$ & $\mathrm{mg} / \mathrm{L}$ & 0.34 & 0.04 & 0.84 & 1.05 & 0.72 \\
$\mathrm{Ni}$ & $\mathrm{mg} / \mathrm{L}$ & $<0.01$ & $<0.01$ & 0.07 & $<0.01$ & 0.35 \\
$\mathrm{~Pb}$ & $\mathrm{mg} / \mathrm{L}$ & $<0.01$ & $<0.01$ & $<0.01$ & $<0.01$ & $<0.01$ \\
$\mathrm{Zn}$ & $\mathrm{mg} / \mathrm{L}$ & 0.18 & 0.37 & 0.14 & 61.92 & 59.77 \\
$\mathrm{Cd}$ & $\mathrm{mg} / \mathrm{L}$ & $<0.0005$ & $<0.0005$ & $<0.0005$ & $<0.0005$ & 0.62 \\
$\mathrm{Fe}$ & $\mathrm{mg} / \mathrm{L}$ & $<0.10$ & $<0.10$ & 242.40 & 775.70 & 1335.00 \\
$\mathrm{As}$ & $\mathrm{mg} / \mathrm{L}$ & $<0.01$ & $<0.01$ & 0.01 & $<0.01$ & 9.25 \\
$\mathrm{Hg}$ & $\mathrm{mg} / \mathrm{L}$ & $<0.0005$ & $<0.0005$ & $<0.0005$ & $<0.0005$ & $<0.0005$ \\
\hline
\end{tabular}

Table 6. Organic compound concentrations in Produced Formation Water (PFW) samples from three offshore gas platforms in the Adriatic Sea (Italy).

\begin{tabular}{|c|c|c|c|c|}
\hline \multicolumn{2}{|c|}{ Analytes } & \multirow{2}{*}{$\frac{\text { PFW1 }(\boldsymbol{\mu g} / \mathbf{L})}{256.0}$} & \multirow{2}{*}{$\frac{\operatorname{PFW2}(\boldsymbol{\mu g} / \mathbf{L})}{10.4}$} & \multirow{2}{*}{$\frac{\text { PFW3 }(\boldsymbol{\mu g} / \mathbf{L})}{20.4}$} \\
\hline & Benzene & & & \\
\hline \multirow{4}{*}{$\begin{array}{c}\text { BTEX } \\
\text { (unfiltered sample) }\end{array}$} & Toluene & 50.6 & 14.1 & 12.1 \\
\hline & Ethyllbenzene & 115.2 & 7.7 & 13.8 \\
\hline & Xilenes (o,m,p-xylene) & 860.0 & 14.8 & 20.2 \\
\hline & BTEX & 1281.8 & 47.0 & 66.5 \\
\hline \multirow[t]{9}{*}{ DEG (unfiltered sample) } & Diethylene glycol & 2400 & 9600 & 13000 \\
\hline & Naphtalene & 14 & 8 & 11 \\
\hline & Acenaphtylene & 21 & 15 & 17 \\
\hline & Acenaphthene & 19 & 15 & 15 \\
\hline & Fluorene & 16 & 4 & 6 \\
\hline & Phenanthrene & 13 & 8 & 10 \\
\hline & Anthracene & 4 & 4 & 7 \\
\hline & Fluorantrene & 12 & 10 & 12 \\
\hline & Pyrene & 10 & 7 & 10 \\
\hline \multirow{10}{*}{$\begin{array}{c}\text { PAHs } \\
\text { (particulate sample) }\end{array}$} & Benzo(a)anthracene & 8 & 4 & 7 \\
\hline & Crysene & 5 & 6 & 7 \\
\hline & Benzo(b)fluorantene & 6 & 4 & 4 \\
\hline & Benzo(k)fluorantene & 6 & 5 & 6 \\
\hline & Benzo(a)pyrene & 5 & 3 & 3 \\
\hline & Dibenzo(a,h)anthracene & 4 & 4 & 4 \\
\hline & Benzo(g,h,i)perylene & 4 & 3 & 4 \\
\hline & Indenopyrene & 3 & $<1$ & 3 \\
\hline & PAHs 2- 3 ring congeners & 87 & 54 & 66 \\
\hline & PAHs & 150 & 100 & 126 \\
\hline
\end{tabular}

butdid show evidence of a toxic response at the $\mathrm{EC}_{20}$ level. The $\mathrm{EC}_{50}$ data lied within or were higher than the range (5.54-20.73\%) previously reported for another filtered PFW originated from an Italian gas platform and assayed by bacteria and sea urchins [14]. Ours $\mathrm{EC}_{50}$ data also were higher than values related to unfiltered $\mathrm{PFW}_{\mathrm{s}}$ coming from the North Sea platforms [4-8]. This shows that the filtered samples have generally lower toxicity than the untreated samples.

The difference of sensitivity among the species has been quite remarkable: T. fulvus and D. labrax showed the highest toxicity $\left(\mathrm{EC}_{50}<50 \%\right.$ ), followed by $V$. fischeri $\left(\mathrm{EC}_{20}<30 \%\right)$. Artemia and the two algae did not record significant toxic effect $\left(\mathrm{EC}_{20}>50 \%\right)$. 
In addition to the toxicity assessment, we analyzed chemically PFW (metals, BTEX, PAHs and DEG). Appreciable concentrations of $\mathrm{Ba}, \mathrm{Mn}$ and $\mathrm{Zn}$ were recorded in filtered samples while also high quantities of Fe were registered in particulate samples. $\mathrm{Ba}$ is probably related to drilling fluid residuals of PFW [7], Zn may be derived from corrosion or chipping of galvanized structures on the platform or in the oil/water separator system [34] and Fe could have natural origin or derive from corrosive events. The lower weight aromatic hydrocarbons (BTEX) were found by significant concentrations in liquid phase, while the PAHs were recorded only on particulate samples. DEG concentrations also were of milligram order in liquid phase but very low compared to the threshold of $3500 \mathrm{mg} / \mathrm{L}$ imposed by the PFW discharge authorization decrees issued by the Italian Ministry of the Environment.

An integrated evaluation of the eco-toxicological and chemical results showed that test-organisms were especially sensitive when exposed to $\mathrm{PFW}_{\mathrm{s}}$ containing $\mathrm{Ba}$, $\mathrm{Mn}, \mathrm{Zn}$ and BTEX. T. fulvus and D. labrax showed the highest toxicity in PFW2 containing high concentrations of $\mathrm{Ba}, \mathrm{Mn}$ and $\mathrm{Zn}$. V. fischeri showed the highest toxic effect in PFW1 that recorded the highest quantities of BTEX. Nobody among the test-organisms indicated a preference for PFW3 containing the highest value of DEG. Moreover, DEG is not toxic alone but could determine co-solvent effects with other chemical compounds [35].

\section{CONCLUSIONS}

Our results indicate that a filtration treatment might diminish PFW toxicity. If a similar treatment was carried out on the platform before the PFW discharge, the ecological risk associated to the discharge would be probably reduced.

Besides, the results confirm the different sensitivity of test-organisms belonging to different trophic levels. Because PFW chemical composition is so variable for type and concentration of contaminants, test-organisms that are tolerant to a type of PFW could be sensitive to others. For this reason, we think that it is not correct to establish a single species to investigate the $\mathrm{PFW}_{\mathrm{s}}$ but a battery of species should always be applied in order to have integrated responses.

\section{ACKNOWLEDGEMENTS}

The present work was funded by the Italian Ministry of Environment, Land and Sea. We thank Lucio Lattanzi for analysis of BTEX and PAHs, Achille Cappiello and Giorgio Famiglini for DEG analysis, Manuela Dattolo, Silvia Mariotti and Antonella Cozzolino for metal analysis. The authors acknowledge B. Trabucco for constructive comments. We thank the Aquaculture Plant Nuovo
Azzurro (Civitavecchia, Roma-Italy) for providing the larvae of Dicentrarchus labrax.

\section{REFERENCES}

[1] Trefry, J.H., Naito, K.L., Trocine, R.P. and Metz, S. (1995) Distribution and bioaccumulation of heavy metals from produced water discharges to the Gulf of Mexico. Water Science Technology, 32, 2, 31-36.

[2] Decree of Environmental Ministry 190 of July 28 (1994) G. U. n. 190 16/08/1994.

[3] Brendehaugh, J., Johnsen, S., Bryne, K.H., Gjose, A.L., Eide, T.H. and Aamot, E. (1992) Toxicity testing and chemical characterization of produced water: A preliminary study. In: Ray, J.P. and Engelhart, F.R. Eds, Produced Water Technological/Environmental Issues and Solutions, Plenum Press, New York, 245-256.

[4] Schiff, K.C., Reish, D.J., Anderson, J.W. and Bay, S.M. (1992) A comparative evaluation of produced water toxicity. In: Ray, J.P. and Engelhart, F.R. Eds, Produced Water Technological/Environmental Issues and Solutions, Plenum Press, New York, 199-208.

[5] Sommerville, H.J., Bennett, D., Davenport, J.N., Holt, M.S., Lynes, A. and Mahieau, A. (1987) Environmental effect of produced water from North Sea oil operations. Marine Pollution Bulletin, 18, 549-558.

[6] Stephenson, M.T. (1992) A survey of produced water studies. In: Reed, M. and Johnsen, S. Eds. Produced Water 2 Environmental Issues and Mitigation Technologies, Plenum Press, New York, 1-11.

[7] Stromgren, T., Sorstrom, S.E., Schou, L., Kaarstad, I., Aunaas, T. and Brakstad, O.G. (1995) Acute toxic effects of produced water in relation to chemical composition and dispersion. Marine Environmental Research, 40, 147-169.

[8] Utvik, T.I.R. (1999) Chemical characterization of produced water from four offshore oil production platforms in the North Sea. Chemosphere, 39, 15, 2593-2606.

[9] Scott, K.A., Yeats, P., Wohlgeschaffen, G., Dalziel, J., Niven, S. and Lee, K. (2007) Precipitation of heavy metals in produced water: Influence on contaminant transport and toxicity. Marine Environmental Research, 63, 146-167.

[10] Cicero, A.M., Di Mento, R., Gabellini, M., Maggi, C., Trabucco, B., Astorri, M. and Ferraro, M. (2003) Monitoring of environmental impact resulting from offshore oil and gas installations in the Adriatic Sea: Preliminary evaluations. Annali di Chimica, 93, 701-705.

[11] Maggi, C., Trabucco, B., Mannozzi, M., Di Mento, R., Gabellino, M., Manfra, L., Nonnis, O., Virno Lamberti, C. and Cicero, A.M. (2007) A methodological approach to study the environmental impact of oil and gas offshore platforms. Rapp. Comm. Int. Mer Médit., 38.

[12] Mariani, L., Manfra, L., Maggi, C., Savorelli, F., Di Mento, R. and Cicero, A.M. (2004) Produced formation waters: A preliminary study on chemical characterization and acute toxicity by using fish larve Dicentrarcus labrax L., 1758. Fresenius Environmental Bulletin, 13, 1427-1432.

[13] Faraponova, O., Onorati, F., Magaletti, E. and Virno Lamberti, C. (2007a) Sensitivity of Tigriopus fulvus (Copepoda, Harpacticoida) towards diethilene glycol (DEG) and produced formation water (PFW). International Meiofauna Conference-Recife, Brazil, 89.

[14] Manfra, L., Moltedo, G., Virno Lamberti, C., Maggi, C., Finora, M.G., Gabellino, M., Giuliani, S., Onorati, F., Di 
Mento, R. and Cicero A.M. (2007) Metal content and toxicity of produced formation water (PFW): Study of the possible effects of the discharge on marine environment. Archives of Environmental Contamination and Toxicology, 53, 183-190.

[15] Manfra, L., De Nicola, E., Maggi, C., Zambianchi, E., Caramello, D., Toscano, A., Cianelli, D. and Cicero, A.M. Submitted Exposure of rotifers, crustaceans and sea urchins to produced formation water and seawaters collected in a gas platform area. Journal of the Marine Biological Association.

[16] Prego, R., Cottè, M.H., Cobelo Garcìa, A. and Martin, J.M. (2006) Trace metals in the water column of the Vigo Ria: Offshore exchange in mid-winter conditions. Estuarine Costal and Shelf Science, 68, 289-296.

[17] Weyerhaeuser (2005) Material safety data sheet MSDS WC 379-01 Rev. 8/26/2005, 1-7.

[18] Azur Environmental (1995) Microtox ${ }^{\circledR}$ acute toxicity basic test procedures, 63.

[19] ISO (2004) Water quality: Determination of the inhibitory effect of water samples on the light emission of Vibrio fischeri (luminescent bacteria test)-Part 3: Method using freeze-dried bacteria. ISO/CD, 11348-3.

[20] ISO (2006) Water quality: Marine algal growth inhibition test with Skeletonema costatum and Phaeodactylum tricornutum. Reference number ISO 10253:2006, 12.

[21] IRSA (1978) Metodologia di saggio algale per lo studio di acque marine. Quaderni dell'Istituto di Ricerca sulle Acque, IRSA-CNR, Milano, 39.

[22] APAT-IRSA-CNR (2003) Metodo 8060. Metodo di valutazione della tossicità acuta con Artemia sp. In: APATIRSA-CNR, Metodi analitici per le acque, Manuali e Linee Guida 29/2003, Volume Terzo, 1043-1049.

[23] ISO/FDIS (1998) Water quality: Determination of acute lethal toxicity to marine copepods (Copepoda, Crustacea). ISO/FDIS, 16, 14669.

[24] Faraponova, O., De Pascale, D., Onorati, F. and Finoia, M.G. (2005) Tigriopus fulvus (Copepoda, Harpacticoda) as a target species in biological assays. Meiofauna Marina, 14, 91-95.

[25] Faraponova, O., Virno Lamberti, C. and Onorati, F. (2007b) Study intensification of Tigriopus fulvus (Copepoda, Harpacticoida) as a target species in bioassays. International
Meiofauna Conference-ecife, Brazil, 90.

[26] EPA (1993) Methods for measuring the acute toxicity of effluents and receiving waters to freshwaters and marine organisms. EPA/600/4-90/027F, Environmental Protection Agency, Cincinnati, Ohio, 71-91.

[27] OECD (1992) Guideline for testing of chemicals $\mathrm{n}^{\circ} 203$. Fish, Acute Toxicity Test, 1-9.

[28] EPA (1998) Mercury in solids and solutions by thermal decomposition, amalgamation, and atomic absorption spectrophotometry Method 7473. Environmental Protection Agency, Cincinnati, Ohio.

[29] EPA (1996) Volatile organic compounds by gas chromatography/mass spectrometry (GC/MS) Method 8260B (Revision 2). Environmental Protection Agency, Cincinnati, Ohio.

[30] Cappiello, A., Famiglini, G., Mangani, F. and Palma, P. (2001) New trends in the application of electron ionization to liquid chromatography-mass spectrometry interfacing. Mass Spectrom. Rev., 20, 88-104.

[31] Cappiello, A., Famiglini, G., Mangani, F. and Palma, P. (2002) A simple approach for coupling liquid chromatography and electron ionization mass spectrometry. J. Am. Soc. Mass. Spectrom., 13, 265-273.

[32] Cappiello, A., Famiglini, G. and Palma, P. (2003) Electron ionization for LC/MS. Analytical Chemistry, 75, 497A-503A.

[33] Cappiello, A., Famiglini, G., Palma, P., Pierini, E., Trufelli, H., Maggi, C., Manfra, L. and Mannozzi, M. (2007) Application of nano-FIA-Direct-EI-MS to determine diethylene glycol in produced formation water discharges and seawater samples. Chemosphere, 69, 554-560.

[34] Neff, J.M., Sauer, T.C. and Maciolek, N. (1992) Composition, fate and effects of produced water discharges to nearshore marine waters. In: Ray J.P. and Engelhart F.R. Eds, Produced Water Technological/Environmental Issues and Solutions, Plenum Press, New York, 371-385.

[35] Sorensen, J.A., Gallagher, J.R., Hawthorne, S.B. and Aulich, T.R. (2000) Gas Industry Groundwater Research Program, Final Report for U.S. Department of Energy National Energy Technology Laboratory Cooperative Agreement No. DE-FC26-98FT40321; Energy \& Environmental Research Center Publication 2004-EERC07-01, Grand Forks, ND. 